\title{
Crossing the Rhine: Germany during the Early Principate
}

\author{
Leah Brochu
}

\begin{abstract}
This paper examines the relationship between early Germany and Rome following the defeat of the Romans in Germany in 9 BCE. The theories of several historians as to why the Romans did not try to conquer Germany and how the loss affected the Romans following the defeat.
\end{abstract}

In 9 B.C.E the Roman army suffered a significant defeat in Germany. Under the generalship of Quinctilius Varus "...three legions were cut to pieces with their general, his lieutenants, and all the auxiliaries." Until this defeat the Roman territory in the North reached the Elbe River in Eastern Germany, and after the defeat it never again reached this distance. Unfortunately there is little documentation of this battle and its consequences, both the immediate ones and the effects it may have had on the decisions of the emperors after Augustus regarding campaigning in the North. The closest near-contemporary source is Velleius Paterculus, but his work is lacking in details. Paterculus writes, "The details of this terrible calamity...I shall endeavor to set forth, as others have done, in my larger work." "These 'larger works' have not come down to us, and from the limited accounts that we do have, there are a surprising number of modern works that seem to overestimate the importance of this affair. ${ }^{3}$ It cannot be denied that the Roman army suffered and lost many men in this battle, but the Romans did not stop conquering altogether at this point. The loss does seem to have affected how the Romans after Augustus operated in this area, however, a number of theories have been put forth by scholars as to why this may be - why the Romans did not try to conquer this area - but none are completely convincing. There is a suggestion that the emperors after Augustus were simply acting in accordance with the boundaries that he had reached, as laid out in his Res Gestae. ${ }^{4}$ It is also thought that it may have been because conquest past the Rhine was not financially advantageous, or because the Rhine River was a natural and logical frontier, which could be easily defended. It is also possible that due to the severity of the loss, the Romans were psychologically scarred when it came to conquest of the lands past the Rhine.

\section{Beyond the Rhine}

In 55 B.C. Julius Caesar crossed the Rhine into Germany. According to Caesar, he did this because "since he saw the Germans were so easily urged to go into Gaul, he desired they should have their fears for their own territories, when they discovered that the army of the Roman people both could and dared pass the Rhine." German tribes had recently crossed over to the Western (i.e. the Roman) side of the Rhine, though Caesar's army was able to put them down, Caesar may have been fearful of people who were brave enough to stand up to the Roman army. Caesar constructed a bridge and crossed to the East side of the Rhine, having “... burned all their villages and houses, and

\footnotetext{
${ }^{1}$ Suetonius, Lives of the Twelve Caesars, Augustus, 23.1.

${ }^{2}$ Velleius Paterculus, The Roman History, 119.1.

${ }^{3}$ For example, Peter S. Wells's The Battle that Stopped Rome, or Adrian Murdoch's Rome's Greatest Defeat.

${ }^{4}$ Res Gestae, 26-30.

${ }^{5}$ Caesar, Gallic Wars, 4.16.
} 
cut down their corn..." Caesar felt "he had advanced far enough to serve both honor and interest" and "[struck] fear into the Germans", and so returned to Gaul. This report seems suspicious, not least because it comes from Caesar himself. Christopher Mackay writes: "Presumably, he decided that there was little opportunity for glory on the far side of the Rhine." This does seem likely, especially given the Roman's weak knowledge of geography - Caesar could hardly have known how much land lay beyond the Rhine and as long as the territory, which he had already conquered (i.e. Gaul) was secure, he had no reason to advance into this forest, which could be treacherous.

\section{The Augustan Army in Germany}

What was true of Caesar was not also true of Augustus. The next foray past the Rhine was in 13 B.C.E, during Augustus's expansion and settling of the areas that were to become parts of the Roman Empire. This campaign was led by one of Augustus's stepsons - Drusus - who "in 12 and again in 9 B.C.E crossed the Rhine and defeated a number of German tribes..." It was during these campaigns that the Roman frontiers reached the Elbe River and Drusus established forts along the Elbe and set a fleet along the Rhine. As Roth writes, "Clearly, the Romans intended to stay in Germany." "If this was not the case, the Romans would not have set up stable forts and left men there. It is also thought that at this time, the position in Germany was secure, and the proof offered "is the decision to proceed in A.D. 6 to the next step in Augustus' grand design, the conquest of Bohemia."12 Bohemia was a region to the southeast of Germany, which was inhabited by the Marcomanni, and Wells writes that

\section{"The attack on Bohemia was not a defensive measure, but another act of shameless aggression. If successful, it would have given the Romans a dominating position in Central Europe, including control of the headwaters of the Elbe, and there is no reason to think that it would not have been followed by further advances."13}

It does seem logical that this was Augustus's plan - during much of his reign he was occupied with expanding the empire through conquest and diplomacy, and so it would follow that he planned to continue expanding.

Around the same time that Drusus was campaigning in Germany, his brother Tiberius was campaigning in Pannonia. They were successfully subdued but unfortunately the peace did not last. In $6 \mathrm{AD}$ a revolt erupted in Pannonia, and "Augustus encountered great reluctance to serve in the military when he tried to raise emergency reinforcements in Italy." "This could indicate that there were not enough troops in the area to effectively battle with the Pannonians, so the Romans had to pull back. "A subsequent attack on Moesia by the Dacians and Sarmatians also diverted Roman attention." 15 Susan Mattern writes that this revolt "...is usually perceived as the worst revolt in Rome's history." In the end the Romans were able to quell the revolts and regain control of the

\footnotetext{
${ }^{6}$ Ibid., 4.19.

7 Ibid.

8 Ibid.

${ }^{9}$ Christopher Mackay, The Breakdown of the Roman Republic (New York: Cambridge University Press, 2009$), 258$.

${ }^{10}$ Jonathan P. Roth, Roman Warfare, (New York: Cambridge University Press, 2009), 155.

11 Ibid., 155.

${ }^{12}$ C.M. Wells, The German Policy of Augustus, (Oxford: Oxford University Press, 1972), 159.

13 Ibid., 161.

14 Mackay, Breakdown, 393.

15 Roth, Warfare, 156.

16 Susan Mattern, Rome and the Enemy, (Los Angeles: University of California Press: 1999)
} 
areas. The troubles in this region may have had an effect on Augustus's future actions in Germany, because this revolt may have pushed him to realize that even the strength of the Roman army could indeed be overcome. This was proved three years later.

In 9 C.E three Roman legions led by Quinctilius Varus were attacked and annihilated by Germans at the Teutoburger forest in Germany. For Augustus, this massive defeat meant that the German conquests past the Rhine had to be abandoned, the Roman position was no longer secure or tenable. Cornell references Creasy who theorized in his book The Fifteen Decisive Battles of the World that Augustus's expansionist spirit was broken by this defeat at the hands of the Germans, and after this defeat Augustus had a very different policy regarding conquest. ${ }^{17}$ While the Varian disaster may not have been a 'Decisive Battle of the World' it was decisive for the reign of Augustus. The loss of so many men at one time had to have been devastating to the hold that Rome could hope to have over Germany, at least for the present time. It should also be considered that Augustus had struggled to gather troops to assist the army in putting down the Pannonian revolts, and thus to attempt to begin to replace three legions would have been a challenge.

\section{After Augustus}

In Tacitus' Annals there is a document Tiberius ordered to be read aloud "Augustus had listed everything in his own handwriting, and had added the recommendation, through fear, perhaps, or from jealousy, that the empire be restricted to its existing frontiers." 18 Once pointed to as a reason that Rome did not again campaign past the Rhine. This argument is not very strong. It is undermined because emperors after Augustus, like Claudius and Trajan, conquered new areas and added them to the Roman Empire. It has also been suggested that the "deathbed instruction in fact emanated from Tiberius, who either invented it or, more probably, forced it upon his ailing stepfather." 19 This is not the most convincing idea, because it is speculative, but if it were true then it would explain why Tiberius did not do much campaigning, and recalled Germanicus from Germany after only two years. Regarding Germanicus' recall from Germany, Tacitus offers another explanation, “...that jealousy was the reason for his being torn away from distinction already won.",20 It could also have been due to the fact that although Germanicus was campaigning against Arminius "with a force ranging from thirty to fifty thousand men...he could not decisively defeat him." 21 The legions that Germanicus was campaigning with had been taken from other places, and since his efforts were not proving successful, keeping these legions away from their designated areas was putting these other areas at a higher risk for invasions and attacks. For Tiberius, then, we have some possible explanations for why he did not try to recapture territory past the Rhine, but what about the emperors after him?

Edward Luttwak's influential work The Grand Strategy of the Roman Empire posits that after withdrawing troops in 16 A.D. Tiberius began to employ a "policy of diplomatic control" instead of attempting to conquer them. According to Luttwak, this policy intended to keep the Germans divided, and thus occupied with warring amongst themselves, and also through "the creation of a chain of client tribes, which would form an active barrier between the perimeters of the empire and

\footnotetext{
${ }^{17}$ Wells, German Policy, 6.

18 Tacitus, Annals, 1.11.

19 Tim Cornell, "The end of Roman imperial expansion” from War and Society in the Roman World, ed. John Rich and Graham Shipley, (London: Routldege, 1993), 148.

20 Tacitus, Annals, 2.26.

${ }^{21}$ Roth, Warfare, 157.
} 
the possibly still more dangerous barbarians deeper inland." 22 This makes a great deal of sense; taking into account the Varian disaster and Germanicus' inability to make much headway, even with so many soldiers, it would be reasonable to implement a new policy in this area. If this is indeed the case, it is possible that the subsequent emperors after Tiberius upheld this policy. Suetonius tells us that the strange emperor Caligula may have had some sort of ill-conceived plans to campaign past the Rhine, but they came to nothing. ${ }^{23}$ After this Claudius made a point of pulling out of Germany, and presumably acting in accordance with Tiberius's plans. Tacitus tells us, "Claudius according forbade any new show of force against the German provinces, to the point of ordering the garrisons to be brought back west of the Rhine." ${ }^{24}$ After this, no further attempts were made to conquer this area.

Luttwak's theory of the frontiers being based on "scientific" or "natural" boundaries does not seem to be applicable to the situation in Germany. This theory has been largely discredited on the whole, as Kagan tells us, ${ }^{25}$ but it is seemingly sensible enough that it deserves to be looked at here with regard to this particular situation. The Roman Empire had to have borders. Luttwak argues that the river frontiers in the North - the Rhine and the Danube - were chosen as the borders, because they were natural stopping places, and were defensible. ${ }^{26}$ This second point - that they were chosen because they were natural barriers is not convincing. It took Caesar only ten days to build a bridge to cross over into Germany, and on this occasion he had also been offered "a large number of ships for transporting the army" by the Ubii. ${ }^{27}$ Thus we can see that a river is not an insurmountable obstacle, and thus was probably not chosen as a frontier for this reason. If this were the case the Elbe would have been just as logical as the Rhine to use as a frontier. Since the Romans had been defeated on the East side of the Rhine however, a position there was not tenable, not because it was unable to be defended, but because they had been defeated and no longer had claim over any territory between the Elbe and the Rhine.

The idea that the Romans did not attempt to conquer past the Rhine because it was not financially worth the effort is a tempting theory, but there is not enough evidence to support it. Appian wrote that "possessing the best parts of the earth and sea the Romans have, on the whole, aimed to preserve their empire by the exercise of prudence, rather than to extend their sway over profitless tribes of barbarians." 28 This comes across as a type of post hoc ergo propter hoc reasoning. Had the Romans conquered any more or any less, there is no doubt that it would have been justified as well. Cornell states that what Appian wrote "... was no more than an excuse for their failure to go farther; it served to explain, or rather to explain away, the fact that the conquest of the orbis terrarium, so confidently predicted in the time of Caesar and the early years of Augustus, had not in fact materialized." 29 What this tells us is that the ancient sources are of little assistance when looking for the reasons why the frontiers were where they were, and that it will continue to be open to interpretation.

\footnotetext{
22 Edward Luttwak, The Grand Strategy of the Roman Empire, (Baltimore: The Johns Hopkins University Press, 1976), 36. 
If the goal of Roman conquest was to only conquer places that would prove to be economically advantageous, then the conquest of Britain does not make sense. In this same vein it cannot be said that the Romans did not campaign past the Rhine because it did not offer wealth. In his article, Cornell asks "Was expansion too expensive?" and writes, "It is absurd to suggest that people and places beyond the Rhine and Danube were too impoverished to yield significant amounts of booty, and were in this respect different from Spain in the second century BC or Gaul in the time of Julius Caesar." ${ }^{30}$ It should be noted that Augustus clearly saw the region as being desirable, as well as areas beyond it, and it was only a military defeat that stopped him from keeping the region beyond the Rhine, and pushing farther.

One reason that may have contributed to the Romans' decision to stay West of the Rhine is the psychological effect that the Varian disaster could have had on them. Susan Mattern talks about the psychological impact that the Roman army had on the places they conquered, and this idea can be turned around to look at the Varian disaster. Roman campaigns had not been without losses before, but this particular defeat was unusual because it involved the death of so many soldiers, happened very quickly, and it took place in territory that the Romans had already supposedly taken over. It also involved the betrayal of a trusted German, Arminius, and seems to have had a direct impact on Augustus's plans. This betrayal could have led future emperors to distrust Germans, and since the areas beyond the Rhine were densely forested it would have been challenging to campaign in them without someone familiar with the land. So then the land beyond the Rhine became unknown territory, which was marked with the blood of thousands of Romans, and so perhaps it would not have been considered wise to attempt to conquer this now mysterious land, which held the memory of a great Roman defeat.

The Roman emperors after Augustus did continue to campaign and conquer, and they were likely driven as much by military glory as by possible financial gain. Regions other than Germany were likely more desirable because they had not already been gained and lost, and also, as the three legions that perished in Germany were never replaced there was thus no force in place in that area. It seems strange that although the army was now made up of a permanent soldiery, as opposed to the ad hoc raising up of troops, which was common in the Republic, no further attempts were made to capture the land beyond the Rhine. The best explanation for this is a combination of reasons. Some emperors, like Tiberius, may have felt inclined to obey Augustus's reported advice to stay within the boundaries he reached, and chose to employ diplomacy over aggression. Germany was very forested, and if Caesar was telling the truth about there being very little there that was desirable, later emperors may have felt inclined to spend their manpower and energies on more promising regions. Finally, there is the Varian disaster. I certainly do not agree with Peter S. Wells, who wrote, "The psychological effect of the crushing defeat on Augustus and his successors contributed to their ending the policy of military expansion not just in Europe but in Africa and Asia as well." ${ }^{31}$ This inflammatory statement does not take into account the fact that Augustus was about 72 (extremely aged for this time!) when this defeat occurred, and that he no longer actively campaigned may have had more to do with his declining health than his desires. It also ignores Claudius's expansion into Britain and Trajan's defeat of Dacia. However, it does seem apparent that the disaster did have an effect on Roman policies of expansion into Germany; they never again conquered past the Rhine to the Elbe, and instead took the Empire in different directions.

30 Cornell, "Roman imperial expansion", 148-149.

31 Wells, The Battle that Stopped Rome, (New York: W.W. Norton and Company, 2003), 15. 


\section{Bibliography}

Appian, Preface.

http://www.perseus.tufts.edu/hopper/text?doc $=$ Perseus $\% 3$ Atext $\% 3$ A1999.01.0230\%3Atex $\mathrm{t} \% 3$ DPref. $\% 3$ Achapter $\% 3 \mathrm{D} 1 \% 3$ Asection $\% 3 \mathrm{D} 1$

Caesar, Gallic Wars.

http://classics.mit.edu/Caesar/gallic.4.4.html

Cornell,Tim. "The end of Roman imperial expansion" War and Society in the Roman World, ed. John Rich and Graham Shipley. London: Routledge, 1993.

Kagan, Kimberly, "Redefining Roman Grand Strategy," The Journal of Military History Vol. 70 No. 2 (2006): 333-362.

Luttwak, Edward. The Grand Strategy of the Roman Empire. Baltimore: The Johns Hopkins University Press, 1976.

Mackay,Christopher. The Breakdown of the Roman Republic. New York: Cambridge University Press, 2009.

Mattern, Susan. Rome and the Enemy. Los Angeles: University of California Press: 1999.

Roth, Jonathan P. Roman Warfare. New York: Cambridge University Press, 2009.

Suetonius, Lives of the Twelve Caesars. http://penelope.uchicago.edu/Thayer/E/Roman/Texts/Suetonius/12Caesars/home.html

Tacitus, Annals. Translated by J.C. Yardley. Oxford: Oxford University Press, 2008 
Velleius Paterculus, The Roman History.

http://penelope.uchicago.edu/Thayer/E/Roman/Texts/Velleius_Paterculus/2D*.html\#11 $\underline{7}$

Wells, C.M. The German Policy of Augustus. Oxford: Oxford University Press, 1972.

Wells, Peter S., The Battle that Stopped Rome. New York: W.W. Norton and Company, 2003. 